\title{
ETIKA SUKSESI DI ORGANISASI DAKWAH
}

\author{
Dhanny Wahyudiyanto \\ STID Al-Hadid, Surabaya \\ dhannywahyudiyanto@stidalhadid.ac.id
}

\begin{abstract}
Abstrak: Elite organisasi dakwah kerap berpolitik di dalam organisasinya. Tindakan mereka terkadang menimbulkan resistensi kader dan anggota, citra negatif dari publik, bahkan sampai menimbulkan perpecahan organisasi dakwahnya. Di sisi lain, berpolitik adalah dorongan alamiah, termasuk dalam proses suksesi kepemimpinan organisasi. Politik organisasi memiliki kepositifan jika dilakukan dengan tujuan dan cara-cara yang baik. Oleh karena itu, tulisan ini dibuat untuk merumuskan etika politik di organisasi dakwah dalam konteks suksesi kepemimpinan. Tulisan ini menggunakan metode kualitatif konseptual dengan pendekatan adaptasi konsep etika politik Islam dan politik organisasi pada konteks suksesi kepemimpinan organisasi dakwah. Hasil studi menunjukkan bahwa etika politik Islam dalam suksesi kepemimpinan organisasi dakwah secara garis besar meliputi aspek tujuan dan cara. Tujuan berpolitik dalam proses suksesi kepemimpinan di organisasi dakwah seharusnya diselaraskan degan tujuan-tujuan organisasi dakwah serta mengarah pada orientasi dasar suksesi kepemimpinan organisasi. Cara mendapatkan kekuasaan menurut etika politik Islam dalam konteks suksesi kepemimpinan organisasi dakwah sebaiknya dilakukan melalui peningkatan kualitas diri yang meliputi aspek idealisme, moral, maupun kemampuan. Dalam proses suksesi yang menggunakan sistem kompetisi, setiap aktor harus menjunjung tinggi sportivitas, menunjukkan kualitas diri secara objektif kepada pemilih. Apabila sistem kompetisi mempertandingkan para kandidat, aktor harus menjaga cara penyampaian produk politiknya agar tidak menimbulkan konflik destruktif.
\end{abstract}

Kata Kunci: Etika Politik Islam, Politik Organisasi, Suksesi Kepemimpinan, Organisasi Dakwah.

SUCCESSION ETHICS IN DA'WAH ORGANIZATION. Abstract: Da'wah organization elites often play organizational politics in their organization. It sometimes leads to resistance among cadres or members, negative image from public, and even cleavage in their da'wah organization. On the other hand, politics is a natural impulse, including in succession process of organizational leadership. Organizational politics has positivity when handled in good goals and ways. Therefore, this paper is written to formulate political ethics in da'wah organization in the context of leadership succession. It uses a conceptual qualitative method by adapting concepts of Islamic political ethics and organizational politics in the context of leadership succession of $\mathrm{da}^{\prime}$ wah organization. It indicates Islamic political ethics in leadership succession broadly include aspects of goals and ways. Political goals in leadership succession must be aligned with da'wah organization's goals and lead to basic orientation of organizational leadership succession. Ways to gain power based on Islamic political ethics in the context of leadership succession should be conducted through self-quality improvements including aspects of idealism, morals, and abilities. In the succession process involving competition system, each actor must uphold sportsmanship, show self-qualities objectively to voters. If it is contesting the candidates, each actor must maintain delivery of political products to not emerge destructive conflicts.

Key words: Islamic Political Ethics, Organizational Politics, Leadership Succession, Da'wah Organization 


\section{Pendahuluan}

Ilmuwan mendefinisikan politik organisasi sebagai tindakan dari seseorang maupun sekelompok orang di organisasi yang bermaksud untuk memperkuat kekuasaannya untuk memengaruhi proses penetapan tujuan, kriteria, maupun pengambilan keputusan organisasi demi memenuhi kepentingannya. ${ }^{1}$ Beberapa lainnya mendefinisikan politik organisasi sebagai tindakan yang senantiasa merujuk pada upaya "melayani diri sendiri" dan "melawan organisasi". Politik organisasi juga merujuk pada tindakan untuk mendapatkan

1 Siswanto, "Politik Dalam Organisasi (Suatu Tinjauan Menuju Etika Berpolitik)," Jurnal Manajemen Pelayanan Kesehatan 10, no. 4 (2007): 161, https://jurnal.ugm.ac.id/jmpk/article/view/2720/244 3.

2 Chris Provis, "Organizational Politics," dalam Handbook of Organizational Politics, ed. oleh Eran Vigoda Gadot dan Amos Drory (Northampton: Edward Elgar, 2006), 91.

${ }^{3}$ Konflik elite sempat terjadi pada perebutan posisi ketua umum Tanfidziyah dalam Muktamar XXXI NU di Boyolali. Selengkapnya baca M Aminudin, "Kemelut Di NU Dan Skenario Penyelesaiannya," Koran.tempo.co, diakses 5 April 2021, https://koran.tempo.co/read/opini/28716/kemelutnu-dan-skenario-penyelesaiannya; Selain itu, pada Muktamar NU ke-33 di Jombang juga terjadi konflik antarelite yang kemudian saling memberikan pengaruh pada kelompoknya untuk mendukung kubunya masing-masing. Bahkan salah satu pihak sempat sampai menggelar muktamar tandingan karena menganggap lawan melakukan tindakan kecurangan dalam proses pemilihan. Selengkapnya baca Hari Tri Wasono dan Sunudyantoro, "NU Terancam Pecah (Kubu Gus Sholah Gelar Muktamar Tandingan)," Tempo.co, diakses 5 April 2021, https://nasional.tempo.co/read/689482/nuterancam-pecah-kubu-gus-sholah-gelar-muktamartandingan/full\&view=ok.

4 Politik organisasi yang negatif juga terjadi di HMI. Meski tidak spesifik, Karim mengungkap maraknya praktik politik transaksional di dalam HMI. Perilaku seperti pemberian akomodasi pendidikan lebih lanjut pada demisioner ketua umum, rolling ketua umum dari satu institusi ke institusi lain, praktik jual beli suara pengaruh yang "terselubung, licik, dan di balik layar". ${ }^{2}$

\section{Pengertian-pengertian bertendensi negatif} tersebut mengacu pada praktik-praktik politik organisasi yang mengabaikan aspek etika. Seperti praktik persaingan antar elite organisasi ketika proses suksesi kepemimpinan yang sempat menimbulkan kegaduhan, $^{3}$ atau adanya upaya-upaya pemanfaatan kekuasaan demi keuntungan pribadi/golongan di organisasi, ${ }^{4}$ atau persaingan pengaruh elite yang mengarah pada perpecahan ketika organisasi hendak meneguhkan identitas maupun khittah perjuangannya. $^{5}$

dalam pemilihan, hingga transaksi penetapan jatah struktur kepengurusan, yang itu semuanya sudah berjalan bertahun-tahun. Selengkapnya di Taufik Z Karim, Otokritik terhadap HMI, ed. oleh Muliansyah Abdurrahman Ways (Yogyakarta: Litera, 2012), 28-29; Selain itu, pada Muktamar NU ke-33, panitia penyelenggara diduga telah memanfaatkan momen untuk mengambill keuntungan politik praktis. Lebih lanjut baca Abdul Hakim Syafi'i, Budhi Gunawan, dan Firman Manan, "Intervensi Partai Politik dalam Suksesi Kepemimpinan Muktamar NU ke 33 di Jombang Tahun 2015," Muktamar NU 11, no. 2 (2019): 221-225, https://doi.org/10.24114/jupiis.v11i2.13622; Politik organisasi yang negatif juga terjadi di Muhammadiyah. Netralitas Muhammadiyah di kancah politik nasional kerap dimanfaatkan oleh pengurus Muhammadiyah di daerah untuk melakukan manuver. Selengkapnya baca Ahmad Sholikin, "Perbedaan Sikap Politik Elektoral Muhammadiyah antara Pusat dan Daerah," Jurnal Polinter 3, no. 2 (2018): 1-22, http://journal.uta45jakarta.ac.id/index.php/polhi/arti cle/view/1080.

${ }^{5}$ Seperti halnya konflik di internal NU pada awal tahun 80 'an yang mengerucut antara kubu Cipete dan kubu Situbondo terkait khittah perjuangan NU. Konflik ini pada akhirnya bisa terselesaikan dengan baik dan NU tidak sampai terpecah belah. Lebih lanjut baca $A b u$ Mujahid, Sejarah NU "Ahlus Sunnah Wal Jama'ah" di Indonesia, Jilid I (Bandung: Toobagus Publishing, 2013), 205-209; Juga seperti perpecahan yang dialami HMI yang menjadi HMI MPO dan HMI DIPO. Pada dasarnya perpecahan tersebut sudah bergeser menjadi kepentingan politik kelompok, bukan lagi didasari atas konflik ideologis. Lengkapnya lihat Sinang Pinasthiko, "Konflik Ideologis Himpunan Mahasiswa Islam (HMI) Pasca Penerapan Azas Tunggal Pancasila 
Politik tanpa etika di dalam organisasi dakwah dapat membuat anggota maupun pengurus organisasi dakwah menjadi resisten, dan mengarah pada perpecahan jika konflik yang diakibatkannya tidak tertangani dengan baik. ${ }^{6}$ Bahkan bila dilakukan secara masif, terbuka, dan konsisten, publik bisa menilai buruk organisasi tersebut. ${ }^{7}$ Politik organisasi yang buruk mengakibatkan kekecewaan pada diri anggota, pengurus, atau karyawan yang ada di dalam organisasi, dan berimplikasi pada tingginya keinginan mereka untuk keluar dari organisasi tersebut. ${ }^{8}$ Politik organisasi yang buruk juga memiliki dampak negatif bagi organizational citizenship behavior para anggota maupun pengurus organisasinya. ${ }^{9}$

Di lain sisi, sebenarnya berpolitik merupakan perilaku alamiah setiap manusia. Sebagai makhluk sosial, manusia harus berinteraksi dengan sesamanya untuk memenuhi kebutuhan yang dimiliki. Agar mendapat keuntungan dan seluruh kebutuhan yang dimiliki bisa terpenuhi maksimal, manusia akan menggunakan kekuasaan yang dimiliki. ${ }^{10}$ Seorang pemimpin yang berkuasa dapat secara efektif memengaruhi perilaku pengikutnya. Dengan kekuasaan, pemimpin

Tahun 1985" (Skripsi-Universitas Airlangga, Surabaya, 2009). http://repository.unair.ac.id/15232/.

${ }^{6}$ M. Ridhah Taqwa, "Resistensi terhadap Praktik Dominasi Kekuasaan dalam Institusi Pendidikan Usia Dini (Studi Kasus Sekolah 'Aizifah' di Yogyakarta)," Jurnal Kependudukan Indonesia 6, no. 1 (2016): 20, http://ejurnal.kependudukan.lipi.go.id/index.php/jki/ article/download/90/158.

7 Imelda. Rettobjaan, “Peranan Humas dalam Merespon Konflik Internal pada Universitas Sam Ratulangi Manado," Acta Diurna Komunikasi 2, no. 4 (2013): 8 ,

https://ejournal.unsrat.ac.id/index.php/actadiurnako munikasi/article/view/2880.

8 Tri Hermawan, Fuad Mas'ud, dan Mirwan Surya Perdhana, "Peran Persepsi Politik Organisasi, Komitmen Afektif, Kepuasan Kerja dan Stres Kerja terhadap Keinginan untuk Keluar dengan Persepsi Dukungan Organisasi sebagai Moderator," Jurnal Bisnis dengan mudah mengambil keputusankeputusan penting dalam waktu singkat secara efektif. Misalnya, dalam memutuskan pengurus yang harus dimutasi, dipecat, diberikan promosi, dan sebagainya. Dalam konteks antar organisasi, dengan kekuasaannya pemimpin dapat menetapkan strategi pertarungan dengan lawanlawannya di eksternal secara cepat, dan tepat tanpa proses konsensus yang kadang rumit dan berbelit-belit. ${ }^{11}$ Arahan, instruksi, perintah, memang lebih efektif jika pihak yang mengeluarkannya memiliki kekuasaan. Karena memang komunikasi lebih efektif jika komunikator memiliki kekuasaan terhadap komunikannya. ${ }^{12}$

Memahami dinamika organisasi dari kacamata politik cukup jarang dilakukan, terlebih dalam konteks organisasi dakwah. Pakar manajemen organisasi lebih banyak tertarik untuk mendalami dinamika manajemen keorganisasian dari pendekatan instrumental. ${ }^{13}$ Padahal, setiap perilaku organisasi memiliki motif yang kadang bersinggungan dengan kekuasaan. Akumulasi sumber daya organisasi termasuk dalam hal ini organisasi dakwah secara nilai

Strategi 27, no. 1 (2018): 35 , https://doi.org/10.14710/jbs.27.1.32-52.

9 Tifanny Dyanisa, Zulkarnain, dan Siti Zahreni, "Pengaruh Kualitas Interaksi Atasan-Bawahan dan Politik Organisasi terhadap Organizational Citizenship Behavior pada Pegawai Negeri Sipil Pemerintah Kota Solok," Psikoislamika : Jurnal Psikologi Islam 14, no. 2 (2017): 32, https://doi.org/10.18860/psi.v14i2.6508.

10 Siswanto, "Politik dalam Organisasi (Suatu Tinjauan Menuju Etika Berpolitik)", 160.

11 Veithzal Rivai dan Deddy Mulyadi, Kepemimpinan dan Perilaku Organisasi, Edisi Keti (Jakarta: Rajawali Press, 2012), 324.

12 Jalaluddin Rahmat, Psikologi Komunikasi, diedit oleh Tjun Surjaman, Edisi Revisi (Bandung: Simbiosa Rekatama Media, 2018), 329-332.

${ }^{13}$ Siswanto, "Politik dalam Organisasi (Suatu Tinjauan Menuju Etika Berpolitik)", 160. 
cenderung lebih besar daripada sumber daya personal-personal (individual) di dalamnya. Sumber daya yang dimaksudkan bisa meliputi sumber daya manusia, sistem kerja, infrastruktur, finansial, jaringan, dan sebagainya. ${ }^{14} \mathrm{Hal}$ ini, membuat para oknum tertarik untuk berpolitik demi kepentingan pribadi maupun kelompoknya dalam organisasi.

Beberapa artikel terkait politik organisasi, kebanyakan terfokus pada persepsi politik organisasi, bukan pada entitas politik organisasinya. Persepsi politik organisasi tersebut menjadi salah satu variabel yang hendak diukur atau dibuktikan hubungan maupun pengaruhnya terhadap variabelvariabel terkait lainnya melalui analisis statistik. $^{15}$

Beberapa yang sudah memfokuskan tulisannya pada kajian politik organisasi, masih sebatas mengeksplorasi isu-isu, konsep-konsep dan teori terkait politik organisasi yang menjadi pijakan (pengantar)

\footnotetext{
${ }^{14}$ Felicia Jesslyn Tanny dan Rooswanti Putri A A, "Sumber Daya Organisasi dan Keunggulan Bersaing Berkelanjutan di Perdana Elektronik," Agora 5, no. 3 (2017): 2,

http://publication.petra.ac.id/index.php/manajemenbisnis/article/view/6091.

${ }^{15}$ H. Gunawan dan T. Santosa, "Politik Organisasi dan Dampaknya terhadap Komitmen Organisasi, Kepuasan Kerja, Kinerja dan Organizational Citizenship Behavior (OCB)," Jurnal Manajemen 12, no. 1 (2012): 15, https://journal.maranatha.edu/index.php/jmm/articl e/view/171. Hermawan, Mas'ud, dan Perdhana, "Peran Persepsi Politik Organisasi, Komitmen Afektif, Kepuasan Kerja dan Stres Kerja terhadap Keinginan untuk Keluar dengan Persepsi Dukungan Organisasi sebagai Moderator," 34-35. Dyanisa, Zulkarnain, dan Zahreni, "Pengaruh Kualitas Interaksi AtasanBawahan Dan Politik Organisasi Terhadap Organizational Citizenship Behavior Pada Pegawai Negeri Sipil Pemerintah Kota Solok," 32.

${ }^{16}$ Siswanto, "Politik dalam Organisasi", 161.

17 Ibid., 164.
}

dalam etika berpolitik. ${ }^{16}$ Namun, proses analisis etika berpolitiknya masih kurang mendalam. Pada kesimpulannya hanya sebatas "perlakukan orang lain sebagaimana kamu menginginkan orang lain memperlakukanmu" dan "jangan lakukan sesuatu pada orang lain yang mana kamu tidak menginginkan orang lain melakukan hal itu kepadamu". ${ }^{17}$ Hal tersebut menimbulkan kesan subjektif pada masingmasing orang. Selain itu, organisasi yang menjadi medan kajiannya juga tidak terkontekstualisasi pada organisasi dakwah. Paramita menulis tentang keterkaitan antara politik dan kekuasaan dalam organisasi secara kualitatif. ${ }^{18}$ Namun, tulisannya tersebut tidak menggunakan perspektif etika, dan organisasi yang menjadi ruang kajiannya juga bukan dalam konteks organisasi dakwah.

Tulisan tentang etika politik, rata-rata hanya mendeskripsikan atau membandingkan pemikiran etika politik tokoh tertentu, ${ }^{19}$ atau sekadar mengacu teks-teks ajaran Islam, ${ }^{20}$

\footnotetext{
18 Patricia Dhiana Paramita, "Keterkaitan antara Politik dan Kekuasaan dalam Organisasi," Dinamika Sains 9, no. 21 (2011): 1-2,

http://jurnal.unpand.ac.id/index.php/dinsain/article/ view/26.

${ }^{19}$ Farhah dan Achmad Farid, "Prinsip Etika Politik Pemimpin dalam Islam," Dauliyah 4, no. 2 (2019): 6870, https://ejournal.unida.gontor.ac.id/index.php/dauliya h/article/view/3306. Rashda Diana, Siswanto Masruri, dan Surwandono Surwandono, "Etika Politik dalam Perspektif al-Mawardi," Tsaqafah 14, no. 2 (2018): 364, https://ejournal.unida.gontor.ac.id/index.php/tsaqafa h/article/view/2433. Muflih Fahmi Kaunain, "Etika Politik Ibnu Khaldun (Analisis Terhadap Konsep Kepemimpinan dalam Muqaddimah)" (Universitas Islam Negeri Sunan Kalijaga, 2017), vi, https://digilib.uin-suka.ac.id/id/eprint/28143/.

20 Achmad Dardirie, "Etika Politik dalam Perspektif AlQur'an," Al-Tadabbur: Kajian Sosial, Peradaban dan Agama 5, no. 1 (2019): 1, http://journal.iainternate.ac.id/index.php/altadabbur/article/view/100.
} 
atau etika politik tokoh tertentu dari tinjauan sejarah, ${ }^{21}$ yang mana kontekskonteks yang dikaji adalah politik dalam lingkup negara, bukan lingkup organisasi. Negara memang merupakan salah satu bentuk dari organisasi. Namun, politik negara memiliki daya kuasa yang secara sah dapat memaksa secara fisik (misalnya pemberlakukan hukuman tahanan, atau bahkan hukuman mati), yang itu tidak dimiliki oleh organisasi lain. Urusan politik negara juga tidak terbatas hanya perkara satu atau dua bidang saja sebagaimana organisasi secara luas, melainkan meliputi pertahanan keamanan, hubungan luar negeri, moneter, penyediaan transportasi dan telekomunikasi, energi, dan lain-lain. ${ }^{22}$

Anas pernah membuat tulisan tentang etika politik organisasi, ${ }^{23}$ namun tulisan tersebut mengacu pada pemikiran etika politik yang digagas tokoh muslim untuk konteks negara, bukan organisasi. Sehingga, rumusannya kurang relevan jika dijadikan acuan standar etis. Adapun tulisan Organizational Politics, Definitions and Ethics, ${ }^{24}$ yang cenderung mengarah pada perbandingan perspektif unitaris dan pluralis dalam memandang politik organisasi. Namun, hasil pemaparan perspektif etika di tulisan tersebut cenderung ambigu dan mengambang. Karena kesimpulannya sebatas

M Thahir Maloko, "Etika Politik dalam Islam," AlDaulah 1, no. 2 (2013): 53,

http://103.55.216.56/index.php/al_daulah/article/vie w/1423.

${ }^{21}$ Kemas Abdul Hai, "Kontekstualisasi Etika Politik Islam Umar Ibn Khattab dalam Kehidupan Kontemporer," Jurnal IImiah Islam Futura 16, no. 1 (2016): 52, doi:10.22373/jiif.v16i1.743.

22 Ramlan Surbakti, Memahami Ilmu Politik (Jakarta: Grasindo, 2007), 20.

${ }^{23}$ M Yusuf Azwar Anas, "Etika Perilaku Politik

Organisasi," Jurnal Dialektika 2, no. 2 (2017): 22-23, mengarahkan agar penilaian baik buruk terhadap setiap perilaku politik organisasi mempertimbangkan aspek-aspek detail yang ada dan tidak bergantung pada organisasi sebagai otoritas moral. Tulisan tersebut juga tidak sampai pada perumusan standar etika politiknya. ${ }^{25}$ Ada pula tulisan tentang panduan pengambilan keputusan etika berpolitik di organisasi. Etika yang digunakan merujuk pada pandangan etika utilitarianis, hak asasi, dan keadilan yang diformulasi menjadi satu kerangka berpikir etis. ${ }^{26}$ Konteks organisasi yang dikaji berlatar organisasi bisnis, bukan organisasi dakwah.

Oleh karena itu, tulisan ini bertujuan untuk membuat rumusan standar etika politik di organisasi dakwah. Namun mengingat luasnya cakupan, sedangkan kapasitas tulisan yang terbatas akhirnya tulisan ini difokuskan hanya pada perilaku politik dalam konteks suksesi kepemimpinan. Tulisan ini merupakan conceptual research dengan pendekatan theory adaptation yang bertujuan untuk memecahkan masalah teori atau konsep yang ada dan menyelesaikan dilema yang teridentifikasi dengan memperkenalkan lensa teoretis baru ${ }^{27}$ terkait politik organisasi, khususnya dalam konteks suksesi kepemimpinan organisasi dakwah dengan perspektif etika politik Islam. Diharapkan tulisan ini, dapat

http://ejournal.uniramalang.ac.id/index.php/dialektik a/article/view/243.

${ }^{24}$ Chris Provis, "Organizational Politics", 92.

25 Ibid., 103-104.

${ }^{26}$ Manuel Velasquez, Dennis J Moberg, dan Gerald F Cavanagh, "Organizational Statesmanship and Dirty Politics (Ethical Guidelines for The Organizational Politician)," Organizational Dynamics 12, no. 2 (1983): 67-68, doi:10.1016/0090-2616(83)90034-7.

${ }^{27}$ Elina Jaakkola, "Designing Conceptual Articles: Four Approaches," AMS Review 10 (2020): 23, doi:10.1007/s13162-020-00161-0. 
menambah khazanah pengembangan teori dan konsep etika politik khususnya dalam konteks suksesi kepemimpinan organisasi dakwah. Hasil tulisan ini, harapannya juga menjadi referensi bagi para manajer, pengurus maupun elite-elite organisasi dakwah ketika hendak melakukan politik dalam suksesi kepemimpinan organisasi agar tidak terjebak pada politik segala cara yang mendatangkan kemudaratan besar.

\section{Etika Politik Islam}

Perilaku yang baik menurut Islam secara umum adalah perilaku yang berorientasi pada pembangunan masyarakat dengan berdasarkan wahyu Allah. Secara operasional, pembangunan masyarakat harus berdasarkan pada hukum-hukum keseimbangan, mengarah pada perbaikan, serta menghindarkan diri dari kerusakan dan bencana. Sedangkan, yang buruk menurut Allah adalah tindakan yang tidak berorientasi pada pembangunan masyarakat, tidak menegakkan hukumhukum keseimbangan, dan berjalan pada hukum kerusakan. Menurut Al-Warisy, untuk menegakkan hukum keseimbangan, diperlukan ilmu pengetahuan yang sesuai dengan objeknya, tidak cukup hanya diperkirakan atau bahkan mengikuti hawa nafsu. Di lain sisi, pada titik tertentu manusia juga tidak dapat menentukan titik keseimbangan bila tidak melibatkan nilainilai ketuhanan. ${ }^{28}$

Sehingga untuk mengkaji etika perpolitikan, harus memahami ilmu pengetahuan tentang politik agar bisa diketahui bagaimana

\footnotetext{
${ }^{28}$ Iskandar Al-Warisy, "Karakteristik Akhlak Islam Menurut Filsafat Akhlak," in Pemikiran Islam IImiah Menjawab Tantangan Zaman, ed. oleh Aminudin et
}

hukum-hukum keseimbangannya, apakah perilaku politiknya mengarah pada perbaikan atau justru kerusakan. Apabila politik yang dikaji spesifik pada konteks tertentu, maka karakteristik dan situasi yang spesifik pada konteks tersebut juga harus dipahami dengan ilmu pengetahuan terkaitnya. Oleh karena itu, dalam tulisan ini nanti juga akan memasukkan konsep-konsep terkait politik organisasi, organisasi dakwah, dan suksesi kepemimpinan yang dilakukan di dalamnya.

Kekuasaan politik lahir secara alamiah dari kebutuhan masyarakat terhadap fungsi pengaturan sosial. Setiap individu memiliki banyak kebutuhan yang harus dipenuhi. Pemenuhan kebutuhan bersama yang cukup kompleks ini perlu diatur agar tidak terjadi chaos. Oleh karena itu, masyarakat mengangkat satu atau beberapa orang di antara mereka sebagai sosok pengatur dalam pemenuhan berbagai kebutuhan yang mereka miliki. Masyarakat memberinya kekuasaan. Oleh karena itu, hakikat kekuasaan pada dasarnya bukan milik pribadi penguasa, melainkan amanah yang diberikan masyarakat untuk tujuan kebaikan masyarakat. Sama halnya dalam konteks organisasi, kedudukan pemimpin juga bukan milik sosok yang menduduki jabatan tersebut, melainkan milik organisasi, dan operasionalisasinya ditujukan untuk kebaikan organisasi.

Tugas pemimpin yang berat mengharuskan seseorang yang menduduki posisi tersebut memiliki beberapa persyaratan. Diantaranya memiliki idealisme dalam berjuang dan

al. (Surabaya: Yayasan Al-Kahfi (Koleksi Interna Perpustakaan STID Al-Hadid), 2012), 155-160. 
berkorban demi Islam (yang dalam hal ini direpresentasikan oleh kiprahnya dalam memperjuangkan pencapaian visi organisasi dakwah), memiliki moralitas dan kepribadian yang baik sehingga bisa menjadi suri tauladan bagi yang selainnya, serta memiliki kemampuan dalam manajerial organisasi. ${ }^{29}$

Untuk mendapatkan sosok pemimpin yang benar-benar terbaik, maka harus ada sistem seleksi yang berdasarkan pada standar pemimpin ideal di atas. Pihak-pihak yang berminat terhadap kekuasaan dipersilahkan untuk ikut serta dalam proses seleksi apabila memenuhi indikator-indikator dari kriteria minimal yang ditentukan. Mereka yang ikut dalam proses seleksi harus tunduk terhadap aturan yang telah ditentukan. Mereka harus menunjukkan diri mereka apa adanya ketika dilakukan proses penilaian oleh pemilih. Tidak boleh ada manipulasi dan pencitraan palsu, agar pihak-pihak yang memiliki kewenangan memilih dapat menentukan pilihannya secara objektif. Di lain sisi, pihak yang memiliki kewenangan memilih, seharusnya juga memiliki acuan indikatorindikator turunan dari kriteria pemimpin ideal. Sehingga, ketika mereka hendak menilai para kandidat dan memutuskan sikap memilihnya, hasilnya bisa akurat dan objektif pada kandidat yang benar-benar terbaik.

Apabila seleksi ditempuh melalui proses kompetisi, maka kandidat yang berlaku sebagai kontestan harus menunjung sportivitas. Meskipun berasal dari dunia olah

${ }^{29}$ Iskandar Al-Warisy, "Etika Politik (Etika Mendapatkan dan Mempertahankan Kekuasaan Internal Organisasi - Negara Menurut Konsepsi Islam)," in Pemikiran Islam IImiah Menjawab Tantangan Zaman, ed. oleh Ika Mariawati dan Sri raga, sportivitas bisa digunakan sebagai acuan dalam persaingan secara luas, termasuk persaingan perebutan kekuasaan di organisasi. Sikap sportif cenderung mementingkan kemenangan secara terhormat dalam persaingan yang dilakukan. Untuk itu, seseorang tidak menempuh jalanjalan yang merendahkan kemenangannya nanti, baik sebelum, saat, maupun setelah persaingan dilakukan. Jalan sportivitas menekankan penerapan aturan yang adil, dan hasil persaingan yang dapat secara seharusnya menunjukkan keunggulan pemenang secara objektif. ${ }^{30}$ Sehingga caracara manipulasi, menipu, membohongi pemilih tidak boleh dilakukan.

Selain itu, sportivitas juga mencakup sikap kesederhanaan tanpa merendahkan pesaing politik saat mendapat kemenangan, serta lapang dada - evaluatif saat menerima kekalahan juga dapat meminimalisir konflik yang terjadi agar tidak menjadi konflik disfungsional atau destruktif yang justru berakibat buruk bagi organisasi dakwah. Emosi sangat mungkin terbawa pada setiap upaya pemenangan yang dilakukan selama kompetisi berjalan. Ketika kompetisi usai dan seseorang dinyatakan kalah, seseorang bisa berpotensi tidak siap untuk menerima kenyataan tersebut. Sikap jemawa dan merendahkan yang dilakukan pemenang dapat menimbulkan peningkatan emosi pada pihak yang kalah. Hal tersebut, akan berlanjut menjadi konflik destruktif jika tidak dihindari sejak awal.

Wahyuni (Surabaya: Yayasan Al-Kahfi (Koleksi Internal Perpustakaan STID AI-Hadid), n.d.), 127.

30 James W Keating, "Sportsmanship as a Moral Category," Ethics 75, no. 1 (1964): 34-35, https://doi.org/10.1086/291517. 
Sehingga, memelihara sikap sportif selama perebutan jabatan di organisasi harus dilakukan oleh para aktor, agar kompetisi yang berjalan benar-benar dapat menghasilkan pemimpin yang terbaik bagi organisasi dakwah dan tidak menimbulkan konflik disfungsional antar kontestan serta para pendukung masing. Bila tidak, kompetisi yang terjadi bisa menjadi interaksi konflik yang saling meniadakan satu sama lain dan justru berakibat negatif terhadap kelangsungan hidup organisasi. ${ }^{31}$

\section{Politik Organisasi}

Awal lahirnya, kajian politik memang masih terfokus mempelajari kekuasaan dalam lingkup negara. ${ }^{32}$ Namun, belakangan ada pandangan terkait politik yang membuatnya dapat ditarik ke dalam konteks organisasi. Pandangan tersebut mendefinisikan politik sebagai usaha memperoleh, mempertahankan, serta melaksanakan dan mempergunakan kekuasaan. Pandangan ini tidak membatasi kekuasaan hanya dalam konteks pemerintahan negara, tetapi mencakup konteks komunitas apapun secara luas. Sebab kekuasaan yang dimaksudkan dalam pandangan ini adalah kemampuan suatu pihak dalam memengaruhi pihak yang lain. ${ }^{33}$ Sehingga berdasarkan definisi ini, politik dapat juga mencakup kekuasaan dalam konteks organisasi. Dalam pengertian yang lebih universal, politik organisasi dapat dipahami sebagai proses di mana beragam kekuasaan

\footnotetext{
31 Selvie M. Tumengkol, "Dinamika Konflik dalam Organisasi," Jurnal LPPM Bidang EkoSosBudKum 3, no. 1 (2017): 52-53.

32 Inu Kencana Syafiie, IImu Politik, Edisi Revisi (Bandung: Rineka Cipta, 2010), 9.

33 Ramlan Surbakti, Memahami Ilmu Politik, 5-6.
}

berjalan dalam sebuah organisasi. ${ }^{34}$ Berjalan yang dimaksudkan adalah dinamika perkembangan, maupun operasionalisasi kekuasaan di organisasi.

Definisi politik organisasi bertendensi negatif yang disampaikan di awal tulisan mengesankan tidak ada celah untuk mengkaji politik organisasi dari tinjauan etika. Sebab, secara aksioma sudah dinilai buruk. Padahal, politik dan kekuasaan bisa dipahami dari perspektif yang seimbang. Nilai etis dari kekuasaan tidak terletak pada kekuasaan itu sendiri. Akan tetapi pada tujuan dan cara yang dilakukan. Seseorang dapat menggunakan kekuasaan untuk kebaikan, yakni untuk tujuan pengembangan sosial, atau juga bisa untuk keburukan, yakni untuk kepentingan pribadi. Tujuan aktor dan perilaku operasionalisasi kekuasaan yang dicapailah yang dapat dinilai keetisannya, bukan instrumen kekuasaan itu sendiri. Seseorang dapat menggunakan kekuasaan tanpa merusak diri maupun orang lain. Hal tersebut, bergantung pada motif dan cara yang digunakan untuk memanfaatkan atau mendapatkan kekuasaan. $^{35}$ Perspektif ini akan memungkinkan adanya konstruksi alternatif pada situasi dan pandangan yang lebih positif, yang memandang politik ataupun kekuasaan secara netral.

Kekuasaan setidaknya memiliki tiga unsur. Yaitu tujuan, cara, dan hasil atas penggunaan kekuasaan. Tujuan kekuasaan

\footnotetext{
${ }^{34}$ Robert Hinck dan Charles Conrad, "Organizational Politics," in The International Encyclopedia of Strategic Communication (John Wiley \& Sons, 2018), 2, doi:10.1002/9781119010722.iesc0125.

35 Gilbert W Fairholm, Organizational Power Politics: Tactics in Organizational Leadership, Second Edition (California: ABC-CLIO, 2009), xiv.
} 
umumnya akan memengaruhi seseorang dalam memilih cara untuk mencari, mendapatkan, mempertahankan, maupun mempergunakan kekuasaan. Jika tujuannya baik, maka cara yang dipilih bisa berkecenderungan baik pula. Juga sebaliknya, jika tujuannya buruk, maka cara yang dipilih bisa jadi juga cenderung buruk. Sedangkan, hasil kekuasaan adalah berkenaan dengan kualitas dan kuantitas pihak-pihak yang berhasil dikuasai. Hasil penggunaan kekuasaan pada dasarnya sekadar implikasi dari dua unsur sebelumnya. ${ }^{36}$ Sehingga, dalam tulisan ini nanti, unsur tujuan dan cara inilah yang akan difokuskan dalam perumusan etikanya dalam konteks suksesi kepemimpinan organisasi dakwah, sedangkan hasil kekuasaan nantinya akan menjadi bagian dari pengukuran kadar baik dan buruk.

\section{Organisasi Dakwah}

Istilah dakwah secara etimologis berasal dari bahasa Arab, yakni da'aa - yad'uu $d a^{\prime}$ watan yang berarti menyeru, memanggil, mengajak, menjamu, mendo'akan, atau memohon. ${ }^{37}$ Dari pendekatan semantik, dakwah bisa bermakna mengajak, berdoa, mengadu, memanggil, meminta, atau mengundang, yang secara prinsip adalah tindakan persuasif atau mengajak manusia lainnya secara halus, dan sehingga tindakan seperti kekerasan, pemaksaan, intimidasi, ancaman, atau teror tidak bisa dimasukkan ke dalam definisi dakwah. ${ }^{38}$ Dakwah

\footnotetext{
${ }^{36}$ Paramita, "Keterkaitan antara Politik dan Kekuasaan dalam Organisasi," 7-8.

37 Ropingi el Ishaq, Pengantar IImu Dakwah: Studi Komperhensif Dakwah dari Teori ke Praktik (Malang: Madani, 2016), 7-8.

38 Moh Ali Aziz, Ilmu Dakwah, Edisi Revisi (Jakarta: Prenada Media, 2016), 6-10.
}

dilakukan untuk mengeluarkan manusia dari kegelapan menuju terang benderang, melalui pengamalan ajaran Islam. ${ }^{39}$ Tujuan dakwah ini seharusnya menjadi ruh bagi setiap pelaku dakwah, baik personal maupun kelompok.

Dakwah memiliki bentuk kegiatan yang beragam, dari yang sifatnya sederhana/kecil hingga yang besar/kompleks. Aktivitas dakwah yang sifatnya kecil, antar perorangan, memiliki muatan hukum fardu ain. Sedangkan, aktivitas dakwah yang bentuknya kompleks memiliki muatan hukum yang diwajibkan pada fardu khifayah. Seperti misalnya, seorang muslim yang memahami makna dan hikmah dari AlQur'an surah Fatihah. Maka, dia memiliki tanggung jawab personal untuk mendakwahkan pengetahuan tersebut kepada mereka yang belum mengetahuinya. Persoalan lain misalnya, dakwah pemberdayaan ekonomi masyarakat muslim dalam satu negara. Maka tanggung jawab dakwah tersebut memiliki hukum fardu kifayah. Sebab hal tersebut, akan membutuhkan banyak tenaga dakwah yang bersifat profesional, dan tidak semua orang bisa melakukannya. ${ }^{40}$

Kelompok-kelompok yang menjalankan tanggung jawab dakwah ini kemudian secara kolektif mendirikan organisasi-organisasi dakwah. Diharapkan dengan pengorganisasian yang baik akan dapat

\footnotetext{
${ }^{39}$ Hamidah, "Perspektif al-Qur'an tentang Dakwah Pendekatan Tematik dan Analisis Semantik," Intizar 19, no. 1 (2013): 9 ,

http://jurnal.radenfatah.ac.id/index.php/intizar/articl e/view/400.

${ }^{40}$ Moh Ali Aziz, Ilmu Dakwah, 154.
} 
memudahkan pencapaian tujuan dari dakwah itu sendiri. ${ }^{41}$

Setiap organisasi, termasuk organisasi dakwah dibentuk dengan tujuan mencapai sasaran tertentu. Affandy menyatakan bahwa dalam konteks dakwah, organisasi adalah alat yang digunakan untuk menjalankan misi dakwah agar dapat mencapai tujuan yang ditentukan secara efektif efisien. Tujuan dari setiap organisasi dakwah dalam hal ini bisa memiliki ragam redaksi, namun secara prinsip tujuan yang seharusnya adalah linier dengan tujuan dakwah secara universal, yaitu mengaktualkan nilai-nilai Islam hingga terbentuk tatanan masyarakat yang baik menurut Allah (thayyibah). ${ }^{42}$ Bahasa lainnya mengeluarkan manusia dari kondisi yang gelap gulita (jahiliah), menuju terang benderang (tayibah) melalui pengamalan ajaran Islam. ${ }^{43}$

Secara bentuk, organisasi dakwah bisa berwujud sebagai organisasi formal maupun informal. Umumnya organisasi dakwah formal bersifat nirlaba. Keuntungan yang didapatkan organisasi hanya akan digunakan kembali untuk menjalankan programprogramnya demi tujuan sosial. ${ }^{44}$

\footnotetext{
${ }^{41}$ I'anatut Thoifah, Manajemen Dakwah: Sejarah dan Konsep (Malang`: Madani, 2015), 39.

42 Shofyan Affandy, Dakwah Strategik (Sebuah Ancangan Teoritis \& Filosofis) (Surabaya: Penerbit Avvaterra, 2017), 25.

${ }^{43}$ Hamidah, "Perspektif al-Qur'an tentang Dakwah Pendekatan Tematik dan Analisis Semantik," 9.

${ }^{44}$ Aldila Dinanti dan Ginanjar Adi Nugraha, "Pelaporan Keuangan Organisasi Nirlaba," Jurnal Ekonomi, Bisnis, dan Akuntansi 20, no. 1 (2018): 3,

http://www.jp.feb.unsoed.ac.id/index.php/jeba/articl e/view/1081

45 Presiden Republik Indonesia, "Undang-Undang Republik Indonesia Nomor 17 Tahun 2013 pasal 10
}

Organisasi dakwah dapat didirikan sebagai organisasi yang berbadan hukum, maupun organisasi yang tidak berbadan hukum. Pada masing-masingnya, organisasi dakwah dapat berbentuk organisasi yang berbasis keanggotaan, maupun organisasi yang tidak berbasis keanggotaan. ${ }^{45}$ Organisasi dakwah berbadan hukum bisa diwujudkan dalam bentuk perkumpulan (berbasis keanggotaan), maupun yayasan (tidak berbasis keanggotaan). ${ }^{46}$ Masing-masing bentuk memiliki karakteristik dan struktur yang berbeda yang diatur lebih lanjut dalam perundangan-undangan yang terkait serta $A D$ dan ART organisasi masing-masing. ${ }^{47}$

Untuk membentuk keteraturan tindakan yang mengarah pada tujuan bersama, organisasi memiliki struktur kepengurusan dan sistem kerja. ${ }^{48}$ Struktur organisasi akan menentukan distribusi kekuasaan di dalam organisasi. Sebab, struktur merupakan pengendali organisasi secara keseluruhan. Melalui tatanan strukturnya, kewenangan pengambilan keputusan dialokasikan ke berbagai posisi. Struktur akan menciptakan kekuasaan dan wewenang secara formal dengan mengkhususkan orang-orang tertentu untuk melaksanakan tugas pekerjaan khusus, dan mengambil keputusan tertentu secara spesifik, serta

ayat $1 a-1 b$, dan ayat $2 a-2 b$ tentang Organisasi Kemasyarakatan, “ Pub. L. No.17 (2013).

46 Ibid, pasal 11 ayat 1, 2 dan 3.

47 Organisasi kemasyarakatan secara umum diatur dalam Undang-Undang Nomor 17 Tahun 2013 tentang Organisasi Kemasyarakatan sebagaimana yang telah diubah dalam Undang-Undang Nomor 16 Tahun 2017. Sedangkan organisasi yang berbentuk yayasan diatur dalam Undang-Undang Nomor 16 Tahun 2001 tentang Yayasan, yang juga telah diubah dalam UndangUndang Nomor 28 Tahun 2004.

48 Rivai dan Mulyadi, Kepemimpinan dan Perilaku Organisasi, 170. 
kemudian dapat mendorong kekuasaan informal melalui dampak ataupun struktur informasi dan komunikasi dalam sistem tersebut. $^{49}$ Selain itu, organisasi juga memiliki tata aturan keorganisasian, ${ }^{50}$ seperti Anggaran Dasar, Anggaran Rumah Tangga, dokumen Standard Operational Procedure, maupun tata aturan lainnya.

Memang tidak semua organisasi memiliki kelengkapan perangkat tujuan, tata kerja dan aturan yang kompleks. Misalnya, organisasi informal, yang cenderung lepas, fleksibel, tidak terformalisasi, dan spontan. Berbeda dengan organisasi formal yang cenderung sangat terstruktur, kaku, terformalisasi, dan sustain. Namun, kenyataan di lapangan tidak ada organisasi yang benar-benar formal, dan tidak ada pula organisasi yang benar-benar informal. Di lapangan, organisasi-organisasi yang ada cenderung berada di antara dua kutub kontinum tersebut. $^{51}$ Organisasi formal cenderung memiliki perangkat-perangkat tujuan, tata kerja, dan aturan yang banyak, kompleks, jelas dan eksplisit. Sebaliknya, perangkat tujuan, tata kerja dan aturan dalam organisasi informal bisa hanya berbentuk konsensus tak tertulis di antara para anggotanya. ${ }^{52}$ Hal yang sama juga berlaku dalam konteks organisasi dakwah. ${ }^{53}$

\footnotetext{
49 Ibid., 346.

${ }^{50}$ Erin L Borry et al., "Formalization and Consistency Heighten Organizational Rule Following: Experimental and Survey Evidence," Public Administration 96, no. 2 (2018): 1, doi:10.1111/padm.12407.

51 J Winardi, Teori Organisasi dan Pengorganisasian, 810.

52 Ibid., 9-10.
}

\section{Suksesi Kepemimpinan di Organisasi Dakwah}

Setiap individu di organisasi pasti mengalami penuaan. Bahkan sebelum memasuki usia tua, ada yang sudah meninggal. Ketika memasuki usia lanjut, berbagai kemampuan tentu sudah tidak lagi fit seperti saat usia muda. Hal ini, berlaku pada individu di level kepengurusan bawah maupun jajaran pimpinan di organisasi. Di lain sisi, organisasi dituntut untuk senantiasa eksis menjalankan beragam misi dan program dakwah agar tujuan bersama yang ditetapkan bisa tercapai. Pemimpin dituntut untuk senantiasa hadir mengomando para bawahannya agar gerak organisasi terarah pada tujuannya. Pemimpin terdahulu yang telah mengalami penurunan kapasitas atau kemampuan, harapannya bisa digantikan melalui proses suksesi oleh pemimpin baru yang secara kualifikasi lebih baik. Oleh karena itu, suksesi kepemimpinan secara alamiah pasti dan perlu dilakukan pada masa-masa tertentu di organisasi. Sehingga, dasar berpikir suksesi sebenarnya dimaksudkan agar organisasi dakwah senantiasa memiliki pemimpin yang terbaik dalam pengelolaannya mencapai tujuan.

Suksesi didefinisikan sebagai perubahan pemimpin formal dari suatu kelompok atau organisasi, baik yang terencana maupun yang tidak terencana. ${ }^{54}$ Berdasarkan definisi ini, suksesi bisa dibedakan dengan momen pemilihan atau pengangkatan pemimpin pada umumnya yang terkadang masih

53 Shofyan Affandy, Dakwah Strategik (Sebuah Ancangan Teoritis \& Filosofis) (Surabaya: Penerbit Avvaterra, 2017), 25.

${ }^{54}$ Humera Manzoor, Nancy Johnson, dan Mehboob ur Rashid, "Emotions During Executive Succession in a Public Board," Journal of Organizational Change Management 31, no. 3 (n.d.): 766-767, doi:10.1108/JOCM-09-2016-0174. 
melibatkan pimpinan sebelumnya sebagai salah satu kandidat. Karena memang realitas yang dirujuk oleh istilah suksesi adalah peristiwa pergantian kepemimpinan. Dengan demikian, fokus telaah etika politik yang akan didalami pada tulisan ini nanti hanya akan mengarah pada tujuan dan cara mendapatkan kekuasaan melalui proses suksesi.

Pada konteks bisnis, suksesi tidak hanya dipelajari sebagai peristwa pergantian kepemimpinan organisasi. Akan tetapi sampai mendalami proses-proses perencanaan dan manajemennya. Diantaranya, mulai dari tahap mempersiapkan beberapa kandidat sebagai calon penerus pimpinan, proses pembinaan para calon pimpinan hingga dipandang siap untuk menggantikan pemimpin terdahulu, hingga proses seleksi mendalam agar didapatkan pemimpin baru yang kualitasnya benar-benar terbaik di antara yang ada. ${ }^{55}$ Sistem umum ini bisa diadopsi dalam konteks organisasi dakwah. Dalam perspektif kepentingan mendapatkan kekuasaan di organisasi, setiap proses tersebut bisa diwarnai oleh manuvermanuver aktor politik. Bahwa seorang aktor bisa berupaya agar dirinya terpilih sebagai salah satu kandidat pengganti pemimpin terdahulu. Seorang aktor bisa berupaya agar selama proses pembinaan, dirinya cenderung dinilai positif oleh pemimpin terdahulu. Seorang aktor bisa berupaya agar dirinya terpilih dalam proses seleksi pemimpin baru untuk organisasi.

55 Yonathan Halim, "Analisa Suksesi Kepemimpinan Pada Perusahaan Keluarga PT. Fajar Artasari di Sidoarjo," Agora 3, no. 1 (2013): 3, http://publication.petra.ac.id/index.php/manajemenbisnis/article/view/1149.
Berfokus pada peristiwa pergantian kekuasaan, sejarah politik Islam klasik menunjukkan bahwa suksesi kepemimpinan pada umat Islam pernah dilakukan melalui beberapa cara. Seperti Abu Bakar yang dipilih menggantikan nabi Muhammad melalui proses pembaiatan, Umar bin Khatab yang dipilih melalui proses penunjukan oleh Abu Bakkar dan didukung oleh para pemuka muslim lainnya, Utsman bin Affan yang dipilih melalui dewan formatur yang dibentuk oleh Umar bin Khatab, Ali bin Abu Thalib yang menduduki kekuasaan karena desakan dari para pemberontak, Muawiyah bin Abu Sufyan yang berkuasa melalui proses perang, arbitrase dan pengkhianatan, lalu para khalifah sesudahnya yang mayoritasnya berkuasa melalui proses pewarisan karena keturunan maupun pemberontakan. ${ }^{56}$

Pergantian kepemimpinan organisasi dakwah sebenarnya telah diatur secara formal oleh aturan perundangan dan $A D$ ART masing-masing organisasi. Secara umum, undang-undang menyatakan bahwa kepengurusan ormas termasuk dalam hal ini juga adalah organisasi dakwah harus dipilih secara musyawarah mufakat. Kepengurusan yang dimaksudkan tersebut setidaknya mencakup unsur ketua, sekretaris, dan bendahara. Untuk teknis mekanismenya diserahkan pada masing-masing organisasi dan ditetapkan dalam AD-ARTnya. ${ }^{57}$ Pelaksanaan suksesi atau pergantian kepengurusan termasuk ketua diserahkan

\footnotetext{
${ }^{56}$ Burhanuddin Yusuf, "Khilafah Rasyidah (Kajian Atas Makna, Fungsi dan Sistem Suksesinya)," Tafsere 3, no. 1 (2015): 118-130, http://journal.uinalauddin.ac.id/index.php/tafsere/article/view/7667.

57 Presiden Republik Indonesia, “Undang-Undang Republik Indonesia nomor 17 tahun 2013, pasal 29
} 
pada masing-masing organisasi yang diatur dalam AD-ART. ${ }^{58} \mathrm{Hal}$ ini, berakibat pada ragam mekanisme suksesi di tiap organisasi yang sangat mungkin berbeda-beda. Misalnya, saja di Nahdlatul Ulama dan Muhammadiyah yang memilih jajaran pimpinannya di tingkat pusat melalui Muktamar, namun dengan teknis dan detail mekanisme yang berbeda. ${ }^{59}$

Sistem pemilihan pimpinan yayasan berbeda dengan ormas yang berbadan hukum perkumpulan. Selain pengurus, yayasan juga memiliki organ pembina dan pengawas. Pembina yayasan memiliki kewenangan untuk mengangkat dan memberhentikan anggota pengurus maupun anggota pengawas. ${ }^{60}$ Pengurus yayasan yang diangkat oleh pembina setidaknya mencakup ketua, sekretaris, dan bendahara. ${ }^{61}$ Masa jabatan pengurus dan pengawas yayasan dibatasi hingga lima tahun, dan dapat diangkat kembali melalui rapat pembina yang mengacu pada Anggaran Dasar yayasan. ${ }^{62}$ Undang-undang tidak membatasi jumlah maksimal periode pengangkatan kembali pengurus yayasan setelah masa jabatannya habis. Namun, pembina dapat memberhentikan anggota pengurus sebelum masa jabatannya habis melalui rapat berdasarkan ketentuan Anggaran Dasar yayasan apabila anggota pengurus tersebut terbukti melakukan

ayat 1 dan 2 tentang Organisasi Kemasyarakatan, “ Pub. L. No.17 (2013).

$58 \mathrm{Ibid}$, pasal 30 ayat 1.

59 Lilis Sarifatul Ajariyah dan Agus Sriyanto, "Wacana Kompas Terhadap Pemberitaan Muktamar NU ke-33 dan Muhammadiyah ke-47," Komunika (Jurnal Dakwah dan Komunikasi) 10, no. 2 (2016): 236-246, doi:10.24090/komunika.v10i2.946.

60 Presiden Republik Indonesia, “Undang-Undang Republik Indonesia nomor 16 tahun 2001, pasal 28 tindakan yang dapat dinilai (oleh pembina) merugikan yayasan. ${ }^{63}$

Berdasarkan beberapa aturan perundangan ini maupun praktik pelaksanaannya di lapangan, sistem suksesi kepemimpinan di organisasi dakwah bisa dilakukan melalui cara yang beragam, berdasarkan situasi konteks organisasi dakwah masing-masing. Hal ini akan berpengaruh pada manuver politik yang berpotensi dilakukan oleh para aktor di tiap-tiap organisasi yang secara pola juga bisa berbeda. Namun secara prinsip, dalam sebuah suksesi yang sistemnya sederhana hingga yang kompleks sekalipun pasti setidaknya terdapat unsur pemilih, dan ada unsur yang dipilih.

Aktor politik yang menginginkan kekuasaan, akan melakukan upaya pengaruh terhadap pihak-pihak yang menjadi pemilih agar memberikan dukungan kepada dirinya sebagai pengganti pemimpin terdahulu. Terlepas apakah pihak yang memiliki hak pilih berasal dari jajaran pengurus organisasi di level bawahnya (sebagaimana ormas yang berbadan hukum perkumpulan pada umumnya dalam memilih pimpinan), ataupun berasal dari organ yang berada di atasnya (sebagaimana pembina yayasan dalam mengangkat pengurus/ketua yayasan). Apabila pihak yang menginginkan kekuasaan atau setidaknya memiliki prospektus menggantikan pemimpin

ayat 2 huruf b tentang Yayasan, " Pub. L. No.16 (2001).

61 Presiden Republik Indonesia, "Undang-Undang Republik Indonesia nomor 28 tahun 2004, pasal 32 ayat 3 huruf a, b dan c tentang Perubahan UndangUndang nomor 16 tahun 2001 tentang Yayasan, "Pub. L. No.28 (2004).

$62 \mathrm{lbid}$, ayat 1 dan 2.

$63 \mathrm{Ibid}$, pasal 32 ayat 4 . 
terdahulu lebih dari satu orang, maka perlu dilakukan proses seleksi, agar yang benarbenar terbaiklah yang menduduki kekuasaan pimpinan.

\section{Etika Politik Islam dalam Suksesi Kepemimpinan di Organisasi Dakwah}

Definisi politik organisasi secara umum berangkat dari pandangan politik kekuasaan. Bahwa politik adalah proses mendapatkan, mempertahankan, maupun menggunakan kekuasaan di masyarakat, yang dalam hal ini juga bisa mencakup ruang lingkup suatu organisasi, termasuk organisasi dakwah. Kekuasaan secara umum memiliki unsur tujuan dan unsur cara, yang keduanya berimplikasi pada unsur hasil yang merupakan akibat dari tujuan dan cara politik yang dilakukan.

Tulisan ini akan mencoba memformulasikan bagaimana tujuan dan cara mendapatkan kekuasaan dalam konteks suksesi kepemimpinan di organisasi dakwah menurut perspektif etika politik Islam.

Tujuan yang Baik Menurut Etika Politik Islam dalam Mendapatkan Kekuasaan Melalui Suksesi Kepemimpinan di Organisasi Dakwah

64 Muhammad Fathurrohman, "Pengorganisasian dalam Perspektif Al-Qur'an dan Al-Hadits (Kajian Tafsir Tematik)," Edukasi (Jurnal Pendidikan Islam) 4, no. 1
Seorang aktor yang menjalankan aktivitas politik selama proses suksesi kepemimpinan di organisasi, pasti memiliki dan terlebih dahulu menetapkan tujuan. Namun, tidak semua tujuan berpolitik di organisasi termasuk tujuan menturutsertakan diri dalam suksesi kepemimpinan pasti bernilai baik. Oleh karena itu, dalam penjabaran yang pertama ini akan dianalisis bagaimana etika bagi seorang aktor ketika menetapkan tujuan aktivitas politiknya dalam proses suksesi kepemimpinan di organisasi dakwah. Secara umum, setiap organisasi dakwah pasti memiliki tujuan-tujuan yang hendak dicapai. Tujuan-tujuan tersebut secara ideal merupakan manifestasi dari tujuan dakwah yang objektif yang telah dibahas pada bagian sebelumnya. Keselarasan tujuan menjadi hal yang mutlak dimiliki setiap elemen organisasi, agar setiap upaya dan kinerja yang dilakukan dapat mengarah pada tujuan dakwah. Apabila ada satu atau beberapa pihak yang memiliki tujuan berbeda atau bahkan bertentangan dengan perangkatperangkat tujuan organisasi dakwah, maka hal tersebut akan berpotensi membuat gerak organisasi tidak efektif-efisien, bahkan dapat membuat organisasi gagal dalam mencapai tujuan dakwah.

Terkait keorganisasian, Allah pernah berfirman dalam Q.S. Ash-Shaff ayat 4 . Secara implisit, ayat tersebut mengandung makna bahwa setiap pihak yang bergabung dalam organisasi hendaknya memperhatikan prinsip pembagian tugas dan wewenang, keselarasan, serta kerja sama dalam mencapai tujuan bersama. ${ }^{64}$ Oleh karena itu, para aktor seharusnya

(2016): 298-299, https://ejournal.staimtulungagung.ac.id/index.php/edukasi/article/view/22 $3 / 178$. 
menyelaraskan kepentingan politik mereka dalam suksesi kepemimpinan organisasi dengan tujuan dakwah organisasi.

Mengarahkan tujuan individual/kelompok (termasuk tujuan berpolitik) pada tujuan organisasi akan memberikan nilai kebaikan yang besar. ${ }^{65}$ Dalam konteks organisasi dakwah, hal tersebut akan mendorong pergerakan organisasi dalam mencapai tujuan-tujuan dakwahnya dengan lebih cepat. Nilai kepositifan yang dirasakan akan lebih besar ketimbang politik yang dilakukan hanya untuk tujuan pribadi maupun golongan. Karena seseorang yang sejak awal memiliki tujuan pribadi (yang berbeda atau bertentangan dengan tujuan organisasi), pada akhirnya segala tindakannya akan diarahkan pada tujuan peribadinya tersebut bahkan meski efeknya buruk bagi organisasi. Kepentingan pribadi memang bisa bertolak belakang, agak bertentangan, bersifat netral terhadap tujuan keorganisasian, tetapi kadang juga bisa sesuai (kompatibel) atau bahkan identik satu sama lain. Salah satu kunci bagi organisasi untuk berhasil adalah upaya bersama dalam mencapai tujuan organisasi yang dapat sekaligus memuaskan sasaran-sasaran pribadi yang bersifat kompatibel itu. Dengan kompatibilitas, pencapaian kepentingan atau tujuan-tujuan organisasi secara otomatis dapat memuaskan kepentingan-kepentingan individu yang ada di dalamnya. ${ }^{66}$

Menurut kajian perilaku organisasi, manajer yang efektif adalah "manajer institusional", yakni mereka yang menggunakan kekuasaan untuk mencapai tujuan (institusional) organisasi. Manajer institusional jauh lebih

65 J Winardi, Teori Organisasi dan Pengorganisasian, 19.

66 lbid.

67 Veithzal Rivai dan Deddy Mulyadi, Kepemimpinan dan Perilaku Organisasi, 346. efektif ketimbang manajer kekuasaan pribadi (personal power manager), yang menggunakan kekuasaan mereka untuk kepentingan pribadi. ${ }^{67}$ Pola perilaku aktor politik organisasi yang semacam inilah yang lebih banyak disoroti oleh beberapa pakar. Mereka mendefinisikan bahwa politik organisasi merupakan perilaku self-serving untuk memaksimalkan self-interest yang pada akhirnya mengorbankan orang lain dan bahkan organisasi secara makro. ${ }^{68}$

Sehingga dari tinjauan ini, dapat disimpulkan bahwa standar etis dalam menetapkan tujuan berpolitik di organisasi adalah selaras dengan tujuan-tujuan organisasi yang objektif. Standar tujuan berpolitik di organisasi dakwah ini akan dikontekstualisasikan lagi secara spesifik pada suksesi kepemimpinan organisasi dakwah.

Sebagaimana yang disampaikan sebelumnya, suksesi kepemimpinan perlu dilakukan karena merupakan kebutuhan alamiah bagi organisasi. Proses suksesi yang baik adalah yang dapat menghasilkan pemimpin terbaik bagi organisasi dakwah saat pemimpin terdahulu harus meletakkan jabatan atau kekuasaannya. Oleh karena itu, setiap aktor harus menjadikan tujuan terpilihnya pemimpin yang terbaik bagi organisasi dakwah sebagai orientasi keturutsertaanya dalam proses suksesi kepemimpinan.

Para aktor yang selama proses suksesi berusaha tampil sebagai yang terbaik di

\footnotetext{
${ }^{68}$ Ali Audah dan Sahat Saragih, "Politik Organisasi dalam Latar Sumber-Sumber Kekuasaan di Lingkungan Kerja," Persona (Jurnal Psikologi Indonesia) 4, no. 3 (2015): 261 doi:https://doi.org/10.30996/persona.v4i03.721.
} 
mata pembina yayasan, atau di mata jajaran pengurus level bawah (dalam konteks ormas berbadan hukum perkumpulan), serta mungkin di mata pimpinan yang akan meletakkan jabatan, perlu merefleksikan ulang, apakah segala tindakan politik mereka dalam suksesi tersebut sudah diarahkan pada tujuan dihasilkannya pemimpin yang terbaik ataukah untuk orientasi lainnya yang justru bertentangan.

Mendudukkan motif kekuasaan selama suksesi secara objektif akan memengaruhi sikap aktor terhadap hasil suksesi yang diikuti. Misalnya, hasil suksesi menunjukkan bahwa seorang aktor tidak terpilih (karena memang faktanya ada yang secara kualitas jauh lebih baik dari dirinya). Aktor yang kepentingannya selaras dengan tujuan dakwah organisasi maupun orientasi dasar suksesi pasti akan berlapang dada serta berevaluasi diri. Atas kekalahan yang objektif tersebut, si aktor akan sibuk membenahi diri, memperbanyak karya dan kontribusi di organisasi dakwahnya sebagai cerminan peningkatan kualitas dirinya yang mungkin sebelumnya dipandang masih kurang. Sehingga, ketika kesempatan suksesi kepemimpinan datang lagi, dan si aktor kembali berkeinginan untuk menggantikan pemimpin yang akan meletakkan jabatan, maka pihak yang memiliki hak pilih akan memberikan penilaian positif terhadap si aktor yang faktanya memang sudah jauh lebih baik daripada momen suksesi sebelumnya.

Hal ini, berbeda dengan aktor yang secara motif bertentangan atau tidak sesuai dengan dasar berpikir dari suksesi. Segala cara akan ditempuh agar dirinya menduduki posisi sebagai pemimpin baru di organisasi. Andaikan dirinya tidak terpilih, maka si aktor akan berusaha mencari-cari jalan untuk mendelegitimasi hasil suksesi, meskipun proses suksesi sudah berjalan sesuai ketentuan dan objektif. Gejolak di organisasi dakwah pun akhirnya terjadi akibat upayaupaya pendelegasian hasil suksesi kepemimpinan.

Baik/buruk tujuan keturutsertaan aktor dalam suksesi akan menjadi kompas bagi aktor dalam berperilaku selama proses suksesi berlangsung. Efek-efek yang muncul dari tindakan politik aktor yang ikut suksesi nantinya tidak hanya mengena pada elemen-elemen yang ada di dalam organisasinya saja, tetapi juga pada masyarakat secara luas. Sebab, organisasi dakwah didirikan untuk menjalankan misi dakwah yang tidak terbatas hanya menyasar untuk para anggota atau pengurusnya saja. Bila keturutsertaan aktor dalam suksesi ditujukan untuk kepentingan pribadi maupun golongan tersebut sampai membuat gagalnya kandidat yang terbaik terpilih sebagai pemimpin yang baru, dan kemudian mengganggu pencapaian tujuan organisasi dakwah secara makro, maka program-program dakwah yang menyasar untuk masyarakat luas juga akan ikut terhambat.

Sebaliknya, jika tujuan aktor turut serta dalam suksesi kepemimpinan sinergis terhadap tujuan-tujuan organisasi dakwah, berparadigma suksesi sebagai alat untuk melahirkan pemimpin baru yang terbaik, maka efek kebaikan tidak hanya terjadi di organisasi, tetapi juga pada masyarakat luas yang menjadi sasaran program-program dakwah organisasi. Implikasi ini tidak hanya berdimensi duniawi, tetapi juga membawa 
efek ukhrawi sebagaimana yang diperintahkan Allah. ${ }^{69}$

Oleh karena itu, aktor yang ikut serta dalam suksesi harus menghayati kembali motif yang terkandung dalam dirinya. Apakah segenap tindakan politiknya dalam proses suksesi dilandasi oleh tujuan dakwah yang objektif serta dimaksudkan agar organisasi dapat memperoleh pemimpin dengan kualitas yang terbaik, ataukah sebenarnya dirinya digerakkan oleh kepentingankepentingan lain yang justru bertentangan dengan nilai-nilai Islam. Misalnya sekadar untuk memperoleh harta, pasangan, menyenangkan keluarganya sendiri, mendapatkan penghargaan sosial, maupun nilai-nilai kebahagiaan duniawi lainnya yang terputus dengan orientasi akhirat.

Selain tujuan, unsur lain dari politik sebagai kekuasaan adalah cara. Cara yang dimaksudkan di sini adalah cara aktor dalam mendapatkan kekuasaan melalui proses suksesi kepemimpinan organisasi dakwah. Meskipun seorang aktor telah memiliki tujuan yang baik dalam mengikuti proses suksesi kepemimpinan di organisasi dakwah, tidak lantas tujuan tersebut menjadikan cara apapun bernilai baik untuk dilakukan. Perlu dasar etika bagi aktor dalam melakukan aktivitas politiknya selama proses suksesi agar dampak-dampak yang ditimbulkan dari tindakannya juga bernilai positif.

\section{Cara yang Baik Menurut Etika Islam dalam Mendapatkan Kekuasaan}

\footnotetext{
${ }^{69}$ Kementerian Agama RI, Al-Quran Andalusia (Solo: Tiga Serangkai Pustaka Mandiri, 2013), 786.

70 Raden Imam Al Hafis dan Moris Adidi Yogia, "Abuse of Power (Tinjauan Terhadap Penyalahgunaan
}

\section{Melalui Suksesi Kepemimpinan di Organisasi Dakwah}

Seperti pemaparan bagian sebelumnya, suksesi kepemimpinan bisa dilakukan melalui beberapa teknis dan mekanisme yang berbeda-beda pada setiap konteks organisasi dakwah. Namun pada prinsipnya, akan selalu ada pihak yang memiliki posisi kunci dalam menetapkan kandidat yang layak menempati posisi pemimpin baru, dan ada pihak-pihak yang ikut serta sebagai kandidat dalam proses suksesi karena ingin mendapatkan kekuasaan.

Seseorang dapat mengendalikan pemikiran hingga tindakan para anggota atau pengurus lain di organisasi melalui kekuasaan yang dimilikinya. Banyak kepentingan pribadi maupun kelompok, termasuk kepentingan organisasi secara makro yang bisa dipenuhi melalui instrumen kekuasaan. Alokasi sumber daya organisasi bisa ditentukan sesuai kehendak penguasa. Hal inilah yang membuat banyak pihak menginginkan kekuasaan dan menjalankan aktivitas politik untuk mendapatkannya, ${ }^{70}$ termasuk ikut serta dalam proses suksesi kepemimpinan.

Disadari atau tidak, setiap aktor yang menginginkan kekuasaan pasti akan berlomba-lomba untuk mendapatkan penilaian yang terbaik dari pihak yang memiliki kewenangan untuk menentukan pilihan, entah dari manapun pihak tersebut berasal, dan dengan konteks seperti apapun situasi organisasi dakwahnya. Baik proses seleksi yang menggunakan kompetisi maupun yang tanpa kompetisi. Untuk mendapatkan pemimpin yang terbaik bagi

Kekuasaan oleh Pejabat Publik di Indonesia)," Publika 3, no. 1 (2017): 80, https://journal.uir.ac.id/index.php/JIAP/article/view/3 494. 
organisasi, para aktor yang menunjukkan dirinya sebagai sosok yang terbaik harus diseleksi secara cermat dan objektif, sehingga keunggulan dan kelemahan dari masing-masingnya bisa diketahui oleh pihakpihak yang memiliki kewenangan untuk memutuskan pilihan.

Proses seleksi yang menggunakan kompetisi dalam tulisan ini dibagi menjadi dua pendekatan. Ada sistem kompetisi yang mengadu para kandidat satu sama lain dalam suatu pertandingan/pertarungan, dan ada sistem kompetisi yang tanpa mengkonfrontasikan para kandidatnya. Pada model kompetisi ini, para kontestan tidak hanya menunjukkan keunggulan diri, tetapi juga tertuntut untuk menyerang keburukan/kelemahan lawannya agar perbandingan kualitas dirinya terlihat semakin jelas dan utuh terhadap lawan. Dalam kontestasi politik negara, baik eksekutif pusat maupun daerah, sistem inilah yang dipergunakan. Masing-masing pasangan calon dibebaskan untuk memasarkan produk-produk politiknya dan sekaligus mengkritik kecacatan dan kelemahan lawan dengan batasan tertentu. Secara istilah dibahasakan sebagai kampanye negatif. ${ }^{71}$

Organisasi dakwah bisa menggunakan sistem seleksi dengan kompetisi yang mengkonfrontasikan para kandidat seperti halnya kontestasi politik nasional dan daerah. Konfrontasi yang dimaksudkan di sini tentu saja proses mengadu visi, misi rencana program pembangunan organisasi yang diusung, maupun rekam jejak yang

\footnotetext{
71 Aisyah Dara Pamungkas dan Ridwan Arifin, "Demokrasi dan Kampanye Hitam dalam Penyelenggaraan Pemilihan Umum di Indonesia (Analisis atas Black Campaign dan Negative
}

mengindikasikan idealisme, moral dan kemampuan para kandidat. Harapannya dengan saling mengadu variabel-variabel tersebut, akan semakin terlihat, siapa sosok yang benar-benar terbaik di antara para kandidat. Sistem ini perlu digunakan apabila konteks organisasi dakwahnya cukup besar/luas cakupan wilayahnya, dan pihakpihak yang dilibatkan sebagai pemilih dalam proses seleksi cukup banyak dan tersebar di berbagai wilayah. Informasi terkait kandidat yang menjadi pijakan pemilih dalam menentukan pilihan dirasa minim. Apabila mereka dipaksakan menentukan pilihan dengan informasi yang terbatas tersebut, dikhawatirkan pilihan yang diambil tidak mencerminkan kondisi objektifnya (memilih kandidat yang bukan terbaik). Sehingga, orientasi dasar suksesi kepemimpinan justru tidak dapat dicapai. Oleh karena itu, melalui sistem ini, masing-masing kandidat dituntut untuk saling mengeksplorasi kelebihan diri dan kekurangan lawannya agar pemilih mendapat informasi yang komprehensif sebelum menentukan pilihan.

Bagi kandidat, penyampaian kampanye positif dan terutama kampanye negatif kepada pihak-pihak yang memiliki hak pilih harus diatur sedemikian rupa agar bil hikmah dan tidak menimbulkan emosi pada kandidat lawan maupun para pendukungnya. Isi penyampaiannya pun harus benar-benar dibatasi pada aspekaspek yang memang dikompetisikan, dan tidak melebar pada hal-hal lainnya yang tidak berhubungan dengan tujuan suksesi. Validitas pesan kampanye harus dipastikan kebenarannya, agar tidak menciptakan

Campaign)," Diktum (Jurnal Syariah dan Hukum) 17, no. 1 (2019): 24-28, doi:10.35905/diktum.v17i1.641. 
persebaran fitnah di organisasi. Itu semua dilakukan agar keputusan pemilih benarbenar objektif, dan kandidat terpilih adalah memang yang terbaik. Sehingga, kandidat yang mendapatkan dukungan terbanyak dari pemilih nanti bisa ditetapkan sebagai pemenang suksesi tanpa penolakan.

Berikutnya adalah sistem kompetisi yang hanya mengarahkan para kandidatnya untuk menunjukkan keunggulan diri mereka masing-masing, tanpa perlu menjatuhkan/menyerang lawan politiknya secara langsung. Sistem ini relatif lebih "dingin" ketimbang model suksesi yang sebelumnya. Karena para aktor tidak tertuntut untuk mengusik dan menjatuhkan lawan secara langsung, melainkan cukup memfokuskan diri pada upaya menunjukkan kualitas diri masing-masing pada pihak-pihak yang menjadi pemilih.

Sistem suksesi ini akan lebih menuntut pihak-pihak yang berperan sebagai pemilih untuk menggali secara dalam informasiinformasi terkait para kandidat. Tidak hanya terkait validitas kepositifan yang disampaikan kandidat, tetapi juga rekam jejak negatif yang masih berkaitan atau berpengaruh bagi kandidat apabila nantinya menjalankan roda organisasi sebagai pemimpin yang baru. Apabila pihak-pihak yang berperan sebagai pemilih tidak memiliki kapasitas yang cukup dalam memvalidasi dan menggali informasiinformasi yang positif maupun negatif tentang para kandidat, baik secara langsung maupun tidak langsung (misalnya melalui pembentukan tim riset independen dari internal), maka sebaiknya organisasi dakwah tidak menggunakan sistem ini. Karena tanpa kapasitas itu, pengambilan keputusan yang dibuat pemilih akan berpotensi tidak objektif, kandidat yang dipilih bisa jadi bukan yang benar-benar terbaik di antara para kandidat yang ada.

Bagi kandidat yang menginginkan kekuasaan dalam konteks suksesi yang dijalankan dengan model ini, kandidat harus benarbenar terbuka dan mengeksplorkan kediriannya apa adanya, termasuk apabila pemilih menanyakan (misalnya dalam proses wawancara) terkait pengalamanpengalaman negatif, catatan kegagalan, maupun kekurangan kandidat yang masih berkaitan dengan variabel-variabel yang tengah dikompetisikan (visi, misi, program pembangunan organisasi yang digagas, rekam jejak yang mencerminkan idealisme, moral maupun kemampuan manajemen organisasi). Tidak boleh ada kebohongan, "asal bapak senang", manipulasi data, maupun "manajemen kesan".

Berikutnya adalah sistem seleksi kandidat yang prosesnya dilakukan secara tertutup. Seleksi tertutup ini diawali dengan proses rekrutmen kandidat yang juga dilakukan secara tertutup. Sistem ini bisa dilakukan oleh organisasi yang data-data dari tiap SDMnya diketahui secara lengkap dan terbarukan, bahkan terdokumentasikan, termasuk data-data terkait para kandidat potensial yang akan diikutsertakan dalam suksesi kepemimpinan.

Sistem ini cenderung lebih efisien, dan cenderung akan dapat membatasi jumlah kandidat yang ikut serta dalam proses suksesi. Mereka yang memiliki hak pilih dalam konteks organisasi ini sendiri yang melakukan rekrutmen terhadap para kandidat. Pemilih akan bergerilya secara selektif untuk menentukan siapa-siapa saja 
yang layak menjadi kandidat. Sehingga, kandidat yang ikut serta dalam bursa suksesi benar-benar SDM-SDM yang unggul dibandingkan selainnya. Biasanya mereka yang sudah ditetapkan sebagai kandidat akan dibina terlebih dahulu agar benarbenar mencapai titik kualitas terbaik dari masing-masingnya. Ketika nanti pemimpin terdahulu harus melepaskan jabatan dan harus ditetapkan sosok penggantinya, pemilih dapat menentukan dari capaian hasil akhir proses pembinaan yang ditempuh, siapa diantara kandidat yang paling layak menggantikan posisi pemimpin terdahulu. Dengan cara ini, organisasi akan mendapatkan pemimpin baru yang terbaik, yang benar-benar mewarisi nilai-nilai pemimpin terdahulunya. Karena pada umumnya proses pembinaan para kandidat sebelum akhirnya dilakukan pemilihan, dilakukan oleh pemimpin terdahulu secara langsung.

Bagi para aktor yang menginginkan kekuasaan pada konteks organisasi yang menggunakan sistem suksesi semacam ini, hendaknya benar-benar menjaga segala tindak tanduknya, kinerjanya, moralitasnya dari hal-hal yang tercela dan merugikan organisasi. Karena setiap perilaku aktor akan terekam dengan baik dan menjadi acuan bagi pemilih untuk melakukan proses rekrutmen kandidat sebagai langkah awal dari proses suksesi kepemimpinan sebelum dilakukan pembinaan dan penentuan pilihan kandidat yang terbaik. Kriteria terbaik untuk calon pemimpin organisasi dakwah sebagaimana yang telah dipaparkan pada bagian sebelumnya setidaknya meliputi kriteria idealisme dalam memperjuangkan nilai-nilai Islam dalam kehidupan bermasyarakat, moralitas dan kepribadian positif yang bisa menjadikannya suri tauladan dan sekaligus mendukung aktivitasnya dalam mengelola organisasi kelak, serta kemampuannya dalam manajemen organisasi dakwah.

\section{Kesimpulan}

Menurut konsep etika politik Islam, tujuan berpolitik di organisasi dakwah, termasuk dalam suksesi kepemimpinan organisasi sebaiknya selaras terhadap tujuan-tujuan organisasi dakwah dan mengarah pada orientasi dasar suksesi kepemimpinan organisasi, yakni untuk mendapatkan pemimpin baru yang terbaik bagi organisasi.

Atas tujuan dasar dari suksesi kepemimpinan tersebut, maka jalan umum bagi setiap aktor yang menginginkan kekuasaan melalui proses suksesi adalah dengan cara menjadikan dirinya sebagai yang terbaik di organisasi. Terbaik dalam hal ini diukur dari aspek idealismenya dalam memperjuangkan pencapaian visi organisasi dakwah, kepribadian dan moralitasnya, serta kemampuan dalam mengelola organisasi dakwah. Menjadikan diri sebagai yang terbaik dalam hal ini harus dilakukan secara substansi, bukan sekedar pencitraan semu/manipulatif. Ini berlaku untuk berbagai sistem suksesi kepemipinan di organisasi dakwah.

Aktor politik yang mengikuti suksesi dengan sistem kompetisi di organisasi dakwahnya harus menunjunjung tinggi sportivitas. Produk-produk politik, data-data terkait diri yang bernilai positif maupun negatif harus disampaikan apa adanya sesuai fakta, untuk menjamin keobjektifan sikap pemilih dalam memberikan penilaian. Dalam konteks kompetisi yang mempertandingkan para kandidat, setiap aktor juga harus menjaga 
cara penyampaian produk-produk politik agar senantiasa bil hikmah dan tidak menimbulkan lawan serta para pendukungnya marah/emosi secara berlebihan.

Tulisan ini dibuat dengan dasar etika politik Islam. Sebagai alternatif lain, studi berikutnya dapat mengembangkan rumusan etika politik dengan perspektif teori-teori etika yang lain sebagai perbandingan. Selain itu, bisa juga mengkaji etika politik dari kasus-kasus perebutan kekuasaan yang terjadi di berbagai organisasi dakwah pada situasi yang spesifik.

\section{Bibliografi}

Affandy, Shofyan. Dakwah Strategik (Sebuah Ancangan Teoritis \& Filosofis). Surabaya: Penerbit Avvaterra, 2017.

Ajariyah, Lilis Sarifatul, dan Agus Sriyanto. "Wacana Kompas Terhadap Pemberitaan Muktamar NU ke-33 dan Muhammadiyah ke-47." Komunika (Jurnal Dakwah dan Komunikasi) 10, no. 2 (2016): 231-252. doi:10.24090/komunika.v10i2.946.

Al-Warisy, Iskandar. "Etika Politik (Etika Mendapatkan dan Mempertahankan Kekuasaan Internal Organisasi - Negara Menurut Konsepsi Islam)." In Pemikiran Islam IImiah Menjawab Tantangan Zaman, diedit oleh Ika Mariawati dan Sri Wahyuni, 110-137. Surabaya: Yayasan AI-Kahfi (Koleksi Internal Perpustakaan STID AI-Hadid), n.d.

- - . "Karakteristik Akhlak Islam Menurut Filsafat Akhlak." In Pemikiran Islam IImiah Menjawab Tantangan Zaman, diedit oleh Aminudin, Bambang Riadi, Dwiroso, Nyimas Nuri S Handayani, Nurhayana, Marina Agustin, dan Sri Wahyuni, 155-160. Surabaya: Yayasan AI-Kahfi (Koleksi Internal Perpustakaan STID Al-Hadid), 2012.

Aminudin, M. "Kemelut di NU dan Skenario Penyelesaiannya." Koran.tempo.co. Diakses 5 April 2021. https://koran.tempo.co/read/opini/28716/kemelut-nu-dan-skenariopenyelesaiannya.

Anas, M Yusuf Azwar. "Etika Perilaku Politik Organisasi." Jurnal Dialektika 2, no. 2 (2017): 1425. http://ejournal.uniramalang.ac.id/index.php/dialektika/article/view/243.

Audah, Ali, dan Sahat Saragih. "Politik Organisasi dalam Latar Sumber-Sumber Kekuasaan di Lingkungan Kerja." Persona (Jurnal Psikologi Indonesia) 4, no. 3 (2015): 259-273. doi:https://doi.org/10.30996/persona.v4i03.721.

Aziz, Moh Ali. Ilmu Dakwah. Edisi Revi. Jakarta: Prenada Media, 2016.

Borry, Erin L, Leisha DeHart-Davis, Wesley Kaufmann, Cullen C Merritt, Zachary Mohr, dan Lars Tummers. "Formalization and Consistency Heighten Organizational Rule Following: Experimental and Survey Evidence." Public Administration 96, no. 2 (2018): 1-18. doi:10.1111/padm.12407.

Dardirie, Achmad. "Etika Politik dalam Perspektif Al-Qur'an." Al-Tadabbur: Kajian Sosial, Peradaban dan Agama 5, no. 1 (2019): 1-19. http://journal.iainternate.ac.id/index.php/altadabbur/article/view/100.

Diana, Rashda, Siswanto Masruri, dan Surwandono Surwandono. "Etika Politik dalam Perspektif al-Mawardi." Tsaqafah 14, no. 2 (2018): 363-384. https://ejournal.unida.gontor.ac.id/index.php/tsaqafah/article/view/2433.

Dinanti, Aldila, dan Ginanjar Adi Nugraha. "Pelaporan Keuangan Organisasi Nirlaba." Jurnal Ekonomi, Bisnis, dan Akuntansi 20, no. 1 (2018): 1-8. 
http://www.jp.feb.unsoed.ac.id/index.php/jeba/article/view/1081.

Dyanisa, Tifanny, Zulkarnain, dan Siti Zahreni. “Pengaruh Kualitas Interaksi Atasan-Bawahan Dan Politik Organisasi Terhadap Organizational Citizenship Behavior Pada Pegawai Negeri Sipil Pemerintah Kota Solok." Psikoislamika : Jurnal Psikologi Islam 14, no. 2 (2017): 2933. doi:10.18860/psi.v14i2.6508.

Fairholm, Gilbert W. Organizational Power Politics: Tactics in Organizational Leadership. Second Edition. California: ABC-CLIO, 2009.

Farhah, dan Achmad Farid. "Prinsip Etika Politik Pemimpin dalam Islam." Dauliyah 4, no. 2 (2019): 66-84.

https://ejournal.unida.gontor.ac.id/index.php/dauliyah/article/view/3306.

Fathurrohman, Muhammad. "Pengorganisasian dalam Perspektif Al-Qur'an dan Al-Hadits (Kajian Tafsir Tematik)." Edukasi (Jurnal Pendidikan Islam) 4, no. 1 (2016): 291-310. https://ejournal.staim-tulungagung.ac.id/index.php/edukasi/article/view/223/178.

Gunawan, H., dan T. Santosa. "Politik Organisasi dan Dampaknya terhadap Komitmen Organisasi, Kepuasan Kerja, Kinerja dan Organizational Citizenship Behavior (OCB)." Jurnal Manajemen 12, no. 1 (2012): 13-26.

https://journal.maranatha.edu/index.php/jmm/article/view/171.

Hafis, Raden Imam Al, dan Moris Adidi Yogia. "Abuse of Power (Tinjauan Terhadap Penyalahgunaan Kekuasaan oleh Pejabat Publik di Indonesia)." Publika 3, no. 1 (2017): 80-88. https://journal.uir.ac.id/index.php/JIAP/article/view/3494.

Hai, Kemas Abdul. "Kontekstualisasi Etika Politik Islam Umar Ibn Khattab dalam Kehidupan Kontemporer." Jurnal Ilmiah Islam Futura 16, no. 1 (2016): 52-73. doi:10.22373/jiif.v16i1.743.

Hakim Syafi'i, Abdul, Budhi Gunawan, dan Firman Manan. "Intervensi Partai Politik dalam Suksesi Kepemimpinan Muktamar NU ke 33 di Jombang Tahun 2015." JUPIIS (Jurnal Pendidikan IImu-IImu Sosial) 11, no. 2 (2019): 213-227. doi:10.24114/jupiis.v11i2.13622.

Halim, Yonathan. "Analisa Suksesi Kepemimpinan Pada Perusahaan Keluarga PT. Fajar Artasari di Sidoarjo." Agora 3, no. 1 (2013): 1-15.

http://publication.petra.ac.id/index.php/manajemen-bisnis/article/view/1149.

Hamidah. "Perspektif al-Qur'an tentang Dakwah Pendekatan Tematik dan Analisis Semantik." Intizar 19, no. 1 (2013): 1-20.

http://jurnal.radenfatah.ac.id/index.php/intizar/article/view/400.

Hermawan, Tri, Fuad Mas'ud, dan Mirwan Surya Perdhana. "Peran Persepsi Politik Organisasi, Komitmen Afektif, Kepuasan Kerja dan Stres Kerja terhadap Keinginan untuk Keluar dengan Persepsi Dukungan Organisasi sebagai Moderator." Jurnal Bisnis Strategi 27, no. 1 (2018): 32-52. doi:10.14710/jbs.27.1.32-52.

Hinck, Robert, dan Charles Conrad. "Organizational Politics." In The International Encyclopedia of Strategic Communication, 1-12. John Wiley \& Sons, 2018. doi:10.1002/9781119010722.iesc0125.

Ishaq, Ropingi el. Pengantar Ilmu Dakwah: Studi Komperhensif Dakwah dari Teori ke Praktik. Malang: Madani, 2016.

Jaakkola, Elina. "Designing Conceptual Articles: Four Approaches." AMS Review 10 (2020): 1826. doi:10.1007/s13162-020-00161-0.

Kaunain, Muflih Fahmi. "Etika Politik Ibnu Khaldun (Analisis Terhadap Konsep Kepemimpinan dalam Muqaddimah)." Universitas Islam Negeri Sunan Kalijaga, 2017. https://digilib.uinsuka.ac.id/id/eprint/28143/.

Keating, James W. "Sportsmanship as a Moral Category." Ethics 75, no. 1 (1964): 25-35. 
doi:10.1086/291517.

Maloko, M Thahir. "Etika Politik dalam Islam." Al-Daulah 1, no. 2 (2013): 50-59. http://103.55.216.56/index.php/al_daulah/article/view/1423.

Manzoor, Humera, Nancy Johnson, dan Mehboob ur Rashid. "Emotions During Executive Succession in a Public Board." Journal of Organizational Change Management 31, no. 3 (n.d.): 766-776. doi:10.1108/JOCM-09-2016-0174.

Mujahid, Abu. Sejarah NU "Ahlus Sunnah Wal Jama'ah" di Indonesia. Jilid I. Bandung: Toobagus Publishing, 2013.

Pamungkas, Aisyah Dara, dan Ridwan Arifin. "Demokrasi dan Kampanye Hitam dalam Penyelenggaraan Pemilihan Umum di Indonesia (Analisis atas Black Campaign dan Negative Campaign)." Diktum (Jurnal Syariah dan Hukum) 17, no. 1 (2019): 16-30. doi:10.35905/diktum.v17i1.641.

Paramita, Patricia Dhiana. "Keterkaitan antara Politik dan Kekuasaan dalam Organisasi." Dinamika Sains 9, no. 21 (2011): 1-13. http://jurnal.unpand.ac.id/index.php/dinsain/article/view/26.

Pinasthiko, Sinang. "Konflik Ideologis Himpunan Mahasiswa Islam (HMI) Pasca Penerapan Azas Tunggal Pancasila Tahun 1985." Universitas Airlangga, 2009. http://repository.unair.ac.id/15232/.

Provis, Chris. "Organizational Politics." In Handbook of Organizational Politics, diedit oleh Eran Vigoda Gadot dan Amos Drory, 89-106. Northampton: Edward Elgar, 2006.

Rahmat, Jalaluddin. Psikologi Komunikasi. Diedit oleh Tjun Surjaman. Edisi Revisi. Bandung: Simbiosa Rekatama Media, 2018.

Rettobjaan, Imelda. "Peranan Humas dalam Merespon Konflik Internal pada Universitas Sam Ratulangi Manado." Acta Diurna Komunikasi 2, no. 4 (2013): 1-13.

https://ejournal.unsrat.ac.id/index.php/actadiurnakomunikasi/article/view/2880.

RI, Kementerian Agama. Al-Quran Andalusia. Solo: Tiga Serangkai Pustaka Mandiri, 2013.

Rivai, Veithzal, dan Deddy Mulyadi. Kepemimpinan dan Perilaku Organisasi. Edisi Ketiga. Jakarta: Rajawali Press, 2012.

Sholikin, Ahmad. "Perbedaan Sikap Politik Elektoral Muhammadiyah antara Pusat dan Daerah." Jurnal Polinter 3, no. 2 (2018): 1-22. http://journal.uta45jakarta.ac.id/index.php/polhi/article/view/1080.

Siswanto. "Politik dalam Organisasi (Suatu Tinjauan Menuju Etika Berpolitik)." Jurnal Manajemen Pelayanan Kesehatan 10, no. 4 (2007): 159-165. https://journal.ugm.ac.id/jmpk/article/viewFile/2720/2443.

Surbakti, Ramlan. Memahami IImu Politik. Jakarta: Grasindo, 2007.

Syafiie, Inu Kencana. IImu Politik. Edisi Revisi. Bandung: Rineka Cipta, 2010.

Tanny, Felicia Jesslyn, dan Rooswanti Putri A A. "Sumber Daya Organisasi dan Keunggulan Bersaing Berkelanjutan di Perdana Elektronik." Agora 5, no. 3 (2017): 1-6. http://publication.petra.ac.id/index.php/manajemen-bisnis/article/view/6091.

Taqwa, M. Ridhah. "Resistensi terhadap Praktik Dominasi Kekuasaan dalam Institusi Pendidikan Usia Dini (Studi Kasus Sekolah 'Aizifah' di Yogyakarta)." Jurnal Kependudukan Indonesia 6, no. 1 (2016): 19-43.

http://ejurnal.kependudukan.lipi.go.id/index.php/jki/article/download/90/158.

Taufik Z Karim. Otokritik terhadap HMI. Diedit oleh Muliansyah Abdurrahman Ways. Yogyakarta: Litera, 2012.

Thoifah, l'anatut. Manajemen Dakwah: Sejarah dan Konsep. Malang: Madani, 2015. 
Tumengkol, Selvie M. “Dinamika Konflik dalam Organisasi." Jurnal LPPM Bidang EkoSosBudKum 3, no. 1 (2017): 47-63.

https://ejournal.unsrat.ac.id/index.php/lppmekososbudkum/article/view/17184.

Velasquez, Manuel, Dennis J Moberg, dan Gerald F Cavanagh. “Organizational Statesmanship and Dirty Politics (Ethical Guidelines for The Organizational Politician)." Organizational Dynamics 12, no. 2 (1983): 65-80. doi:10.1016/0090-2616(83)90034-7.

Wasono, Hari Tri, dan Sunudyantoro. "NU Terancam Pecah (Kubu Gus Sholah Gelar Muktamar Tandingan)." Tempo.co. Diakses 5 April 2021.

https://nasional.tempo.co/read/689482/nu-terancam-pecah-kubu-gus-sholah-gelarmuktamar-tandingan/full\&view=ok.

Winardi, J. Teori Organisasi dan Pengorganisasian. Jakarta: Rajawali Press, 2011.

Yusuf, Burhanuddin. "Khilafah Rasyidah (Kajian Atas Makna, Fungsi dan Sistem Suksesinya)." Tafsere 3, no. 1 (2015): 114-132. http://journal.uinalauddin.ac.id/index.php/tafsere/article/view/7667. 